\title{
Biomedische basisvakken zijn voor de artsopleiding tegenwoordig minder belangrijk ${ }^{1}$
}

\author{
F. Scheele
}

Artsen moeten hun medische expertise goed in praktijk kunnen brengen. Daarvoor zijn sociale vaardigheden nodig. ${ }^{1}$ In het Canadese "CanMEDS 2000"-project is geprobeerd om de stem van de maatschappij een plaats te geven in de profielschets van een goede arts (http:// rcpsc.medical.org/canmeds/canmed_e.html). Maatschappelijke klankbordgroepen speelden daarbij een grote rol. De traditionele rollen van medisch expert en wetenschapper ("het hoofd") worden in het CanMEDSrapport geflankeerd door rollen als communicator, samenwerker, organisator, professional (denk aan gedragscodes) en advocaat voor patiënt en gezondheid ("het hart"). Meerdere basisopleidingen en alle vervolgopleidingen in Nederland, maar ook in Denemarken bouwen inmiddels hun curricula op het CanMEDS-concept. De toekomstige arts wordt nu toegepaste wetenschapper met bagage uit de biomedische hoek, maar met tevens een goede bagage uit onder andere de psychologie, de sociologie en de bestuurskunde. Dat moderne artsen behoefte hebben aan een dergelijk breed profiel blijkt ook uit de klachten tegen artsen en afdelingen van ziekenhuizen. Die betreffen vaak communicatie en professioneel gedrag, maar ook aspecten van samenwerking en organisatie. ${ }^{2}$ Het ontrafelen van praktijktaken moet antwoord leveren op de vraag welke kennis en welke concepten uit deze gammawetenschappen voor een arts belangrijk zijn. De betreffende lesprogramma's worden momenteel verder ontwikkeld. ${ }^{3}$

F. Scheele $(\square)$

Prof. dr. F. Scheele is gynaecoloog.Correspondentieadres:Prof. dr. F. Scheele, Sint Lucas Andreas Ziekenhuis, afd.

Verloskunde en Gynaecologie, Postbus 9243, 1006 AE

Amsterdam.Belangenconflict: geen gemeld.Financiële

ondersteuning: geen gemeld.
Wat de biomedische basiskennis betreft, moet in de komende curriculumbijstellingen voor de artsopleiding een selectie worden gemaakt van die kennis die echt vitaal is voor een goede arts. De selectie is noodzakelijk om plaats te maken voor sociale wetenschappen. Hoe kan er geselecteerd worden? Uit cognitief-psychologisch onderzoek van de groep van Schmidt is het duidelijk dat biomedische kennis een belangrijke rol speelt in de vorming van medische expertise. ${ }^{4} \mathrm{Om}$ tot een efficiënte keuze van deze biomedische kennis te komen, ligt het voor de hand om van de medische praktijk uit te gaan. Medische taken en vaardigheden kunnen worden ontrafeld, ${ }^{4}$ en vervolgens kan worden vastgesteld welke biomedische kennis als ingrediënt voor die taken nodig is. Zo komen wij via retrograde programmeren tot de keuze van een biomedisch lesprogramma. En ook wordt duidelijk met welke klinische kennis en ervaring het biomedische lesprogramma het beste kan worden geïntegreerd.

Vaak wordt het aanbieden van een grote hoeveelheid voor de praktijk weinig relevante basiskennis beargumenteerd met de "noodzaak tot verdieping". Het selectiever aanbieden van kennis uit de biomedische basisvakken hoeft echter geen afbreuk te doen aan die verdieping. Verdieping binnen basisvakken dient weloverwogen, maar exemplarisch te zijn.

In tijd uitgedrukt zal de bijdrage van de biomedische vakken in de opleiding daardoor duidelijk minder zijn dan 20 jaar geleden, maar de kennis die voor de praktijk belangrijk is, blijft behouden. De toegenomen aandacht voor gammawetenschappen moet de arts voorbereiden op een veranderende wereld waarin hij of zij een

\footnotetext{
${ }^{1}$ Dit artikel verschijnt ook in het Nederlands Tijdschrift voor Geneeskunde.
} 
slagvaardig teamlid is, met een kritisch-reflectieve werkhouding.

\section{Summary}

Medical doctors that neglect the roles of communicator, team worker, organizer and professional can be expected to perform inadequately. The content of the training of medical doctors should be reconsidered. A selection should be made of the biomedical sciences that are required during the training for later medical practice. Thus, these basic sciences should, in part, make way for social sciences to ensure the development of team skills. (Scheele F. The basic biomedical subjects are now less important in the training of medical doctors. Dutch Journal of Medical Education 2007;26 (2):91-92.)

\section{Literatuur}

Verheugt F. "Zonder leiding valt de keten uiteen in koninkrijkjes". Vakgroep hartchirurgie Radboud disfunctioneert al jaren. Med Contact 2006;61: 732-4.
Heineman MEF, Hubben JH. Patiëntrechtelijke aspecten. Organisatorische aspecten. In: De gynaecoloog in de medische tuchtrechtspraak 1980- 1992. Nijmegen: Katholieke Universiteit Nijmegen; 1994. p. 153-234.

Borleffs JCC, Borel Rinkes IHM, Mulder H, Knape JTA. Blauwdruk voor een nieuwe opleiding. Med Contact 2005;60:1255-7.

Boshuizen HPA, Schmidt HG. De ontwikkeling van medische expertise; implicaties voor het praktisch en theoretisch medisch onderwijs. In: Metz JCM, Scherpbier AJJA, Vleuten CPM van der, editors. Medisch onderwijs in de praktijk. Assen: Van Gorcum; 1995. p. 25-39. 